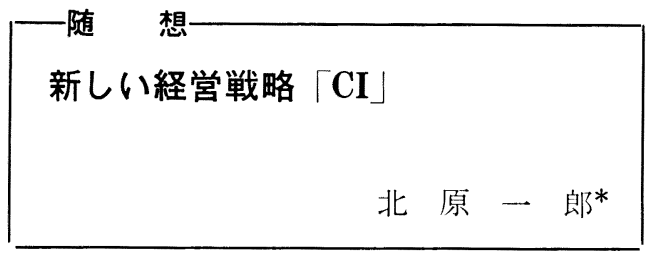

最近，いくつかの企業のマークが，新しくなつたの にお気づきではありませんか，例えば，「ブリヂスト ン」,「東京海上火災」,「三井銀行」, そして, 新発足の 「NTT」，「日本たばこ」など。

マークやロゴタイプ(社名書体)は, いわば企業の顔で す. それを変更するわけですから，よほどの事情がある にちがいありません．もら何十年も同じマークを使つて いるために，時代に合わなくなつて古い感じがするので 変えた, といら単純な理由も一部ではあるでしよらが， 動機がもつと深い部分にある場合がより多いのです.
例えば，企業イメージが低下した，業績が伸び悩んで いる，何らかの事情で，業体が変化した…‥など.実 は，企業のシンボルマークといらのは，これから述べる CI (コーポレート・アイデンティティ) のあくまで一部 でありますそそしてそれは，時の経営者の好みで生まれ るものではもちろんなく，それなりの確たるコンセプト (概念) や戦略に基づいて登場してくるものです.

CI とは, 一言でいえば, “企業のあらゆるコミュニケ ーション活動を整理, 統合し, 企業の意見, イメージを 統一的に伝達するシステム”です.このシステムの汴 リができたのは, 昭和 20 年代. 所は, アメリカです. アメリカ合衆国は，その名のとおり，多人種より成る国 家. 言葉や風俗, 習慣の異なる人たちを相手に, 政府の 欲するところを行らには，他国では見られないいろいろ な努力が要りました．そのよらな国にある企業が，第二 次大戦後の新しい経営戦略として取り入れたのが GI で す. 常に「主義・主張」「統一」「効率」を第一に考える アメリカ人ならではの発明です.

○新しい企業マークの例

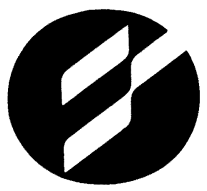

三井飸行

三井銀行

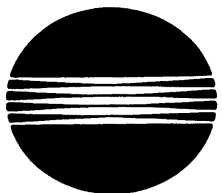

MINOLTA

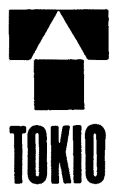

MARINE

WARIIE
東京海上火災

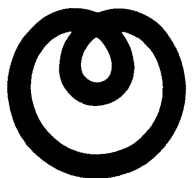

少電信電話

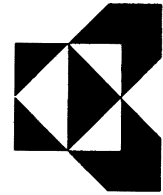

KYOCERב 京 Ł

\title{
$\mathfrak{A V}$ 西曰本銀行
}

\section{MRIDGESTOIE}

ブリヂストン

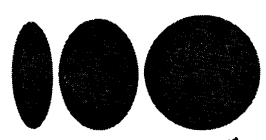

日本たばこ 産業株式会社

*(株) 電通 九州支社 
CI 理論を提唱しはじめたアメリカの人たちが，典型 的な $\mathrm{CI}$ 事例として, 怖れとある種の畏敬の念をるつて 挙げたのが，かのナチス体制です。ナチスは結局崩壊し ましたが，1942 年頃までは，おそるべきアイデンティテ ィを発揮しました。国の目標，党のモットー，国民ひと りひとりが行らべき活動とその意味, 全国にはりめぐら されたいろいろな段階のいろいろな組織, そして, メー ケンクロイッのマークと“ハイルヒトラー”のスローガ ン. “ホルスト・ヴェッセル”の唄. ことに威力をふるつ たのは，耳と目を通じての国民への感性訴求です，ヒ卜 ラー自身のカリスマ性をいかんなく発揮した“獅子吇” ラジオ演説. それに，悪魔的な美しさを持つナチスの軍 服, 制服や旗, ポスター, はては映画にまで表されたデ ザインポリシーがそれです，ある時期までのナチスは， その体制の内部はもちろん，国民とのコミュニケーショ ンにおいても，高いアイデンティティを記録したといえ ましょう。

前置きが長くなりましたが，ここいらで，CI の中味 を多少論理的にお話しいたします。

\section{$\langle 1\rangle$ CI 導入の背景}

（1）生活者の意識変化……生活に必要なモノがひと 通り身のまわりに揃つた今日の成熟社会においては, 生 活者は自分のライフスタイルと合ら思想をるつ企業の商 品を選ぶよらになつた．企業は今やモノを売るために は，まず生活者の考方方，思想を売らねばならなくなつ た.

（2）社会の意識変化……これからは企業が社会的存 在として，その人格を問われる時代. 商品が均質化した 今日では, 商品の微細な違いよりも, 企業の考方方, 社 会的・文化的活動のよしあしが重要になります. 経済的 存在と文化的存在のバランスをとるための企業レベルの コミュニケーション活動が必要である.

（3）企業の状沉変化……企業の成長, 拡大, 社会環 境の目まぐるしい変化・複雑化の中で, 自己の位置づけ が確認しずらくなつてきている．社会の中で自分の果た す役割, 機能を明確にし，これに向けて企業活動を統合 してゆかねばならない。

\section{$\langle 2\rangle$ CI 導入の要因}

・企業イメージが限定, 固定化している

・いい人材が育つていない

・企業としての差別化が必要になつてきている

・企業として何か主張を持ちたい

・企業規模が急に拡大した

・会社案内を作り直す必要がでてきた

・技術開発力が低下した

・特定商品に対する依存度が高すぎる

・ューザー, ターゲットの層が変化している

・消費者意識の変化に対応できない

・商品についてのクレームが多くなつている
・海外依存度が高くなつてきている

・売り上げが低下している.シェアが下がつている.

·事業が多角化している

・企業ロゴ，スローガンを変えたいと思っている

·社訓, 社是が空文化してきている

・組織を横断するプロジェクトがふえている

・事業内容と社名がくい違つている

・企業の向から方向が見党ない

·社員募集に苦労している

・ブランド体制，ネーミング体制の見直しをしたい

・新規事業の参入を考劣ている

・現代に拈ける企業の存在意義を問い直したい

\section{$\langle 3\rangle$ CI の機能}

（1）コミュニケーション機能……看板, 広告, 輸送 車から, 名刺, ニニフォーム, 社内用便箋にいたるま で，統一したデザインの下に，企業の意思・イメージを 浸透させていく視覚的伝達手法が中心となるので，コミ ュニケーションの機会が飛躍的に增大寸る.

（2）マーケティング機能……個々の製品の特性によ る差別化が困難になつている今日，企業イメージを高め ることは, マーケティング戦略上, 必要不可欠である。 特に, 新製品の開発や新分野への参入の場合, イメージ 先行政策が可能になる点は見逃せない，

（3）モラールアップ機能……社内の活性化. 厳しい 企業環境のもとで, 自社のもつ経営資源を有効に利用す る必要性が増大し, 内的活性化のために, 自社の位置づ けと進む方向を明確にすることが今求められる.

$\langle 4\rangle$ CI の構造

（1）マインドアイデンティティ（MI）-—企業の理 念の同一性

これは，CI 計画の要ともいうべき，もつとも重要な 要素である、その企業が，どんな考党で企業存続をはか り, 社会との調和, 共存をもくろんでいるのかを示する のであるからだ. CI を考光る大前提が，この経営理念 の確立であり，それをどら一人一人の社員の心の中に浸 透させ, 定着せしめ, 行動の基盤にするかが, CI の成 果を左右する.

（2）ビへイビヤーアイデンティティ(BI)-一その 企業の構成員一人一人のアクティビティに扑梳 同一性

社員一人一人の行動は, 経営理念を示す重要な要素で ある・どんなに崇高な経営理念を掲げようとも，どんな に立派なデザイン表示計画をたてょらとも，上から下ま で一貫された経営理念を態度で具体的に示す行動が伴わ なかつたら，かえつてそれは社会の不信をかい，企業そ のものの信頼失墜を招くことになるからだ.

(3) ビジュアルアイデンティティ（VI)=その企 業の理念をシンボライズし, 視覚的に展開する表 示上の同一性 
いわば顔づくりである.物いわぬコミュニケーターと しての重要な役割を果たす.

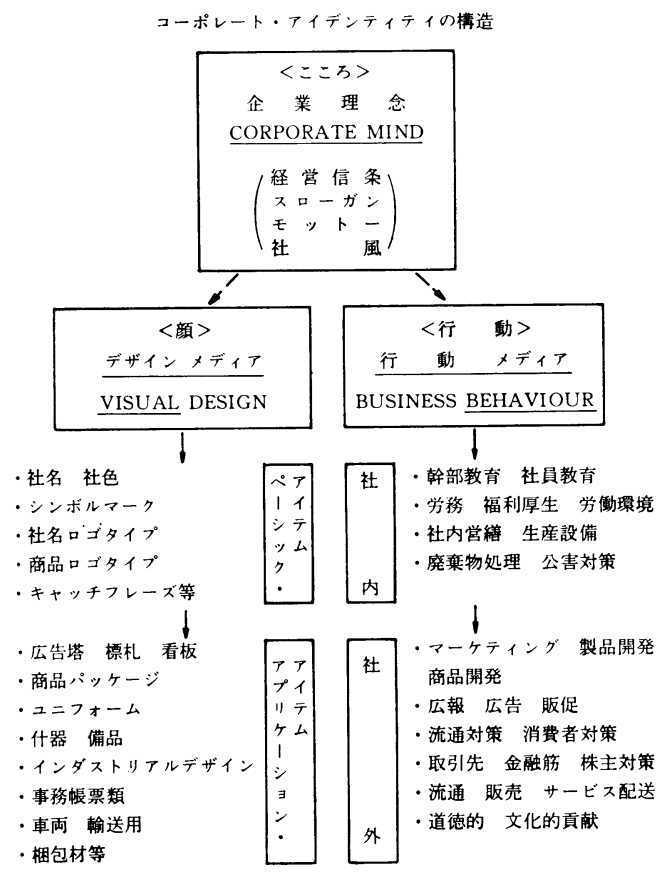

$\langle 5\rangle$ CI 作業の流れ

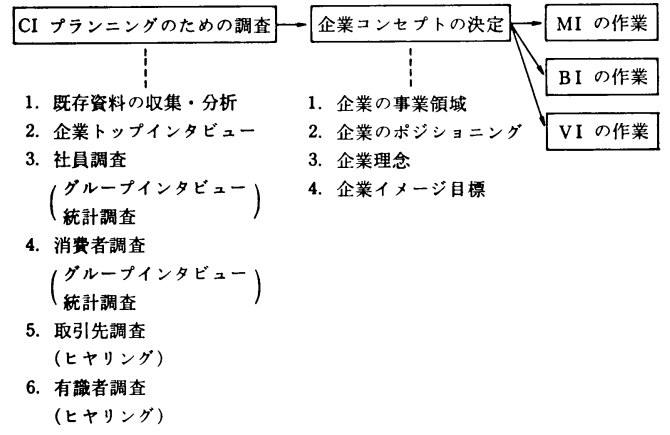

〈6〉エピソード

ではここで， CI にまつわるいくつかのエピソードを ご紹介しましょう.

(1) Aファッションメーカー(若者向け) ……社業が 発展して，アメリカに進出することになつた。 この際, CI を導入して，イメージを一新することとした．そこ で，現在のシンボルマークのアメリカ市民に対するイメ ージ調查を実施.「何をしている会社のマークに見える か」の質問では， 1 鉄鋼会社， 2 化学肥料会社， 3 製薬 会社といら答が大多数を占め, 今さらながら, 現シンボ ルマークと事業内容との不一致を認識。

（2）B百貨店……老舗ゆえに，それまでの行き方に こだわり，次第に衰退. ダウン寸前のところで, CI を
導入. 3 年の年月と巨費を投入，自らを客観視し，企業 としての課題を設定するための内外の諸調査により，そ の地域における百貨店としての新しいポジショニングを 決定（総合的なデパートから，個性的なデパートへ), マーチャンダイズの一新, 人事の刷新, 機構改革, そし て新しいイメージ戦略の確立を行つた。スタート後一年 足らずして，効き目があらわれ，売り上げは上昇，その 百貨店のショッピングバックは，新しいステイタスシン ボルとさえなつた.

（3） $\mathrm{C}$ 銀行……CI の一環として, 新しい行歌（社 歌）が誕生した. そこの行員の一人いわく「頭取の演説 を 10 回聞くよりも，新しい行歌を 1 回歌う方が，銀行 と共に自分も生まれ変わるのだ，といら実感が強くわい てくる」. 音楽は，人間の理性よりも情緒に訴えかける． その強味である.なお，この銀行の行歌には，行名が入 つていないのが特長. ふつら，社名が入つてこその社歌 である.ゆ皃に, 社員一般にとつては“儀式の時の歌” 以上のものではない。しかし，今は音楽に高い感性を示 す若い社員も増えてきた。できれば社歌も“義理で歌う 歌”から，“好きで歌う歌”になつてほしい。そんな願い をこめて，あえて行名をとつたが，それがかえつて好評 のよらである。

（4） D食品会社……I は全社運動である. 始め は, トップダウンの形で, 社長が社員に CI の必要性を 説くが，次第に社員一人一人が「俺なら会社をこら変え てやる」と意気ごんで，ボトムアップの形で意見具伸を 行つたりするのが理想である.しかし，この企業は，始 めから終わりまでトップダウンのままで推移した．途中 においても，終わつてからも，社員はシラケ気味.「ど らも CI の必然性が理解できない. 金ばつかり使つて, トップはいい気なものだ」と批判的.これでは, 逆にモ ラルダウンをきたしてしまう，CI 成功のコッは，いか に社員全員をまきこむかだ。

（5） E精密機器……VI 作業が一段落して，新マー クを世に発表したとたん，「我が社のマークとほとんど同 じではないか」と，さるメーカーから文句をつけられ た、打金と時間をかけた手前，それに何よりもメンッが 大事とあつて， $\mathrm{E}$ 社としては今さらとり下げられない。 「変更できぬ」とつつぱねたところ，裁判に 持ちこまれ た.これは, CI 作業の中でも重要な“マークの類似調 查”を怠つたために, 必然的に起こつた事件である. 、 一ク決定前に，候補案を数案，特許庁に提出して，似た ものがないかどらか調べてもららのが通例である.

以上のよらに， CI とは，せんじつめてみれば，MI (マインドアイデンティティ), BI (ビへイビヤーアイデ ソティティ), VI（ビジュアルアイデンティティ）の三 つから成るものです.とかくVI のみを取り上げて, CI と称しがちですが，それはまちがいです， MI， BI があるからこそ，CI は経営戦略だといわれるのです. 
CI は, “企業価值創造運動” とか “企業再生運動” と もいわれます．実際に，CI を導入して，一段と力をつ けた企業や，つぶれかかつた状態を脱し，見事に立ち直 つた企業も少なくありません．数かぎりなくある企業経 営の方法論の中で, CI は, 「総合的」「客観的」で「シ
ステマティック」なのが特長ですから, 失敗の可能性が 比較的低く，また経済的であります。

新しい時代の経営戦略の一つとして, これからも CI は, 時代の脚光を浴びることでしょう.
コラム

\section{分 析 雑 感}

「ポーラロに飽いたら原子吸光に留まれ!」といら 言葉を一昔前に聞いた。 今は原子吸光から ICP 発光 分析への移行の時とも言光ようか. 分析機器の進歩は 目覚ましい. 分光写真器から光電測光の直読式とな り，その迅速性に驚いていたのもつかの間，データ処 理等のコンピュータ化により, ますます便利になり, 精度, 正確さが向上し, 今や技術の進歩の行く所は予 想もつかない。

分析機器の種類も多岐にわたり, 全体を把握するこ とも困難である。ママイクロビームフナリシス関係では 各種測定法の略語だけでも 62 種類にのぼる(「マイク ロビームアナリシス」日本学術振興会編, 1985)。 米 国 Labscan 社のデータベースには 928 社, 6582 種の 機器が含まれており, 四半期ごとに更新され，検索サ 一ビスに供せられているという(Chem \& Eng. News p. 23, 1984, No. 10).

新材料探索の研究が活発に推進されると共に, 解 析, 計測技術の面での技術的進歩が，いつそう期待さ れている最近である. 微量分析も数 $\mathrm{ppm}$ オーダーか ら数 $\mathrm{ppb}$ オーダーとなり, 今や数 $100 \mathrm{ppb}$ では多量 となり，原子 1 個 1 個を数光る所まで来ている。. 保守 的な国と思ら英国でも産学が協力して分析機器の開発 を目指しているそうである。基礎研究に打ける評価の 高い英国が，その知識を応用面飞生かした時, 期待さ れる成果は大きいのではないかと思ら。

さて, 一方, 地味な湿式化学分析が, 共すると見落 され勝ちである. 材料開発段階では化学量論的分析方 法が必要とされる場合が多い。しかし，熟練した優秀 な湿式分析技術者は少なくなつている。 世代の交替期 にさしかかつている. 大学での基礎的教育と共に, 現 場での技術の伝承が着実に行われることを切に望む所 である. (金属材料技術研究所 大河内春乃) 


\begin{tabular}{|lll|}
\hline プレート随 想—テクトニクスと & \\
海底釷床の誕生 & & \\
& 水 野 篤 行* \\
\hline
\end{tabular}

1970 年代末から 1980 年初頭にかけて, プレートテク トニクス理論の発展の上に, そして新しい有望な海底金 属資源の認識といら上に非常に意義深い, 重要な発見が 東太平洋であいらいでなされた. 水深約 $2600 \mathrm{~m}$ の中央 海嶺中軸部の海底での高温の熱水の地下からの噴出と, 噴出口及びその周辺でのさまざまな金属を含む塊状硫化 物の沈殿一熱水起源の海底鉱床（熱水鉱床）の誕生一の 発見である. 以来, 我が国を含み主要先進国によつて学 術的研究や探査がこの新たに発見された海底鈗床に対し て続けられている(1) 6). 深海底の鈗床といえば, とくに 1970 年代に入つてからマンガン団塊が著しい注目をあ び, 研究・探査, 採掘技術の開発が国際的に活発に行わ れてきたことについては，今さら多言を要しないであろ ら.しかし, かつてマンガン団塊が占めていた“人類に
残された最後の資源”といら座は今や熱水起源(熱水性) の海底鉱床にゆずり渡されることになつたのである。熱 水性の海底鉱床とは，海底下に拈ける熱水作用 (hydrothermal activity) に直接起因して形成される金属沈 殿物集合体のことであり，性状から多金属塊状硫化物 (polymetallic massive sulfide; 以下塊状硫化物鉱床之 よぶ)，鉄マンガン酸化物，重金属泥に大別される．資 源的にもつ之も重要なのは，それらのらち塊状硫化物で ある.とれらは，形成の場やプロセスを異にしている が，いずれにせよ熱水作用に直接起因するといら点で， 直接的には水成 (hydrogenous) の起源を持つマンガン 団塊あるいはマンガンクラストとは，咸因，分布，性状 等あらゆる点で大きく異なつている.

さて，図1をまずみていただきたい、世界の海洋から 海水をとり去つてあらわれた海底の起伏を示すこの図に おいて，まず目につくのは，地球表面をとり巻いている 大山脈一中央海嶺一で，全延長 約 $54000 \mathrm{~km}$ と算定さ れている，その軸部には中軸谷といわれる割れ目が中央 海嶺の延びの方向に発達し, 一部では紅海やカリフォル ニア湾にみられるように大陸のなか、割つて入つたよう な姿を示している，一方，大陸縁辺沿い，あるいはその

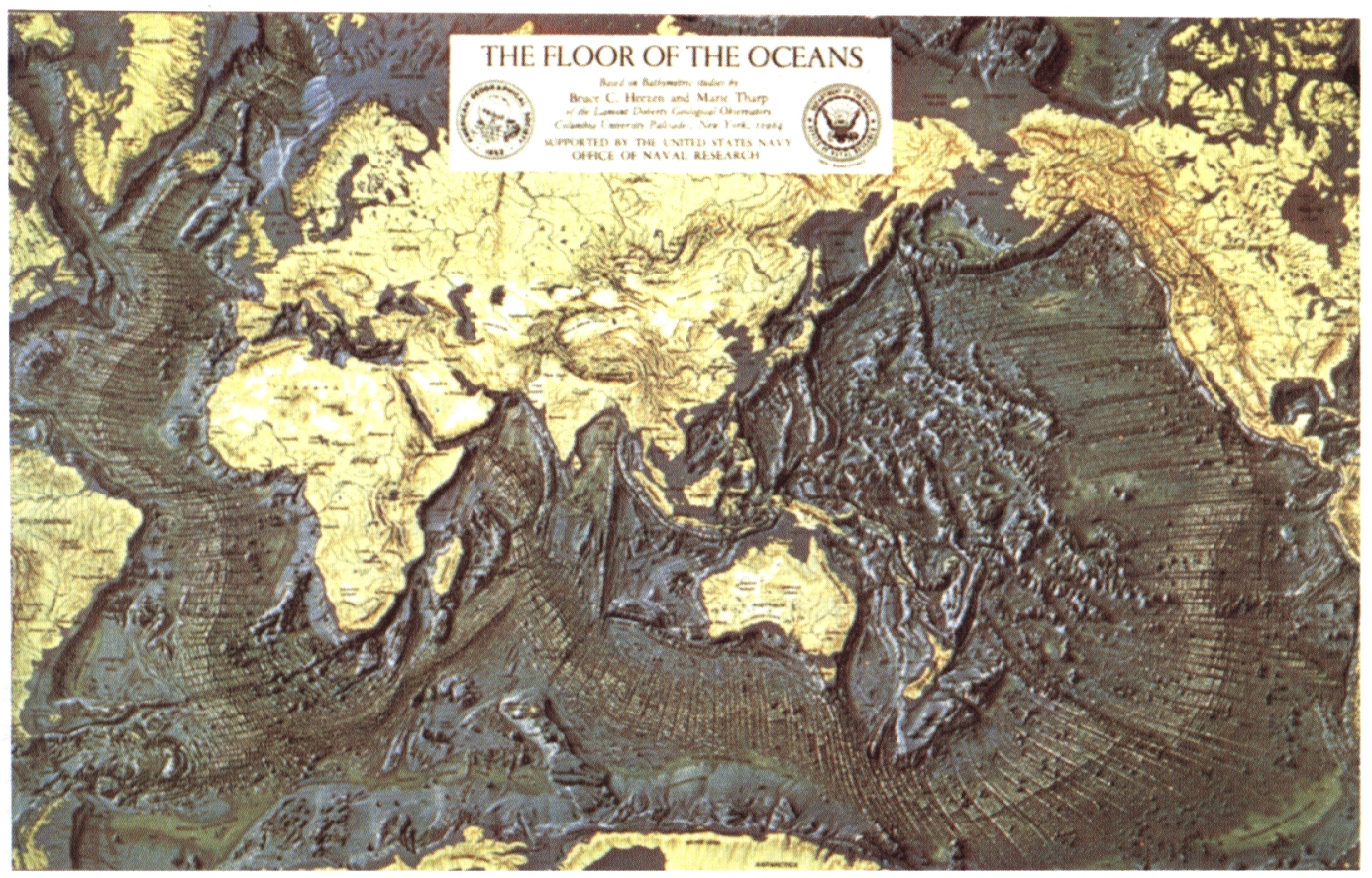

四1 世界の海洋底の起伏図

(The Floor of the Oceans, Marie Tharp による)

中央海顗が地球表面をとりまいている様子がよくわかる。これまて知られている熱水鉱床の大部分は 中央海嶺の軸部ぞいに分布する (図 2 参照)，マンガン団塊はとくに太平洋中東部及びインド洋中央部 の比較的平坦な深海盆飞多く分布する。

* 山口大学理学部 理博 
近くには，深い海溝が細長く走るところがみられ，その 全延長は約 $52000 \mathrm{~km}$ といわれる. そして海溝の大陸 側では，とくに西太平洋域で顕著にみられるが，大小の 背弧海盆が発達するところが多い，

ところで, 中央海嶺において地下深部から高温物質が 上昇して, 新しい海盆をつくり, マントル対流によつて 新しい海底が次々と拡大・移動し, 最後に海溝部で再び マントルにもぐり込んで行く, といら海洋底拡大説が提 唱されたのは 1960 年代初頭のことであつた. この考兄 方は, 諸データのひきつづいての発見・蓄積とあいまつ て 1960 年代末には, 現在世界的に多くの科学者によつ て支持されているプレートテクトニクス説に発展した. プレートテクトニクス説に捄いては, 地球表面が約 100 $\mathrm{km}$ 程度の厚さの剛体的なふるまいをする 10 個程度の リソスフェア（プレート）によつて拈拈われて拈り，そ れらが相対運動を行い, 重要な地球科学的諸現象の多く がそれらの境界部で行われる（過去から未来を通じて） と考える.プレート境界には, 発散型, 収斂型, 平行移 動型の 3 種類が識別される. 熱水性の海底鉱床が形成さ れるのもこのプレート境界，とくに前 2 者が大きな役割 を果たしているのである.

発散型プレート境界はとなりあら二つのプレートが互 いにはなれて行くところであつて, 中央海嶺の払大軸が これに相当する.ここでは，アセノスフェアから高温の 溶融状態にあるマグマが㧨大軸そのものである中軸谷の 割れ目に沿つて上昇し冷却・固結して大洋底玄武岩から なる新しいリソスフェアを形成して行く、マグマは海底 に到達し，海底では常に火山活動が行われている．形成

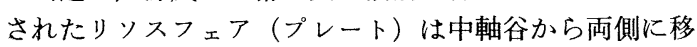
動し，そのすき間を埋めるよらな形で順次新しいリンス フェアが付加されて行く. 中軸谷の周辺は常に伸長性テ クトニクス場にあり, 多数の正断層や割れ目が形成され ている、また，その地下深部では断層や割れ目を通じて 渗透した海水と高温のマグマあるいは固結した岩石との 反応によつて高温かつ金属に富化された熱水 (hydrothermalliquid) が形成され，その上方への移動に伴つ て海底下及び海底に熱水起源の金属化合物（熱水鉱床） が沈澱する。

このよらなタイプの海底熱水鉱床が最初に発見された のは, 海洋底扗大説が提唱されて間もなく, 1960 年代 の中頃，紅海の中軸谷に颃いてであつた。すなわち，紅 海の中軸谷の一部の凹地の海底に亜鉛・銅 - 銀等に富む 重金属泥が唯積し, その上を $56^{\circ} \mathrm{C}$ に達する高温塩水が おおつていることが明らかにされた．この発見は，海洋 底拡大説の正当性を支持するものとして，末た中央海嶺 の拡大軸においてどのような地学的現象が捄こつている かといらことに対する一つの key を提供したものとし て, 科学者を勇気づけた。 そして, 潜水調査船を使用し ての 1970 年代前半の大西洋中央海嶺中軸谷に対する詳
細な米仏共同の FAMOUS 計画に発展し，さらに 1970 年代後半の東太平洋海膨（以下 EPR という）をはじめ とする, 東太平洋の中央海嶺桩大軸における米仏による 詳細な研究へと発展した．先に述べたように，熱水鉱床 には重金属泥のほか，鉄マンガン酸化物（低温，酸化 型)，多金属塊状硫化物（高温，環元型）の両者が知られ ている. FAMOUS 計画の研究によつて, 大西洋中央 海嶺の拡大軸の地質地球物理学的特徽の詳細が明らかに されると共に熱水起源の低温型鉄マンガン酸化物の沈 澱, 熱水作用の存在が明らかにされた。 EPR 等の東太 平洋の拡大軸に対しては, ひきつついて同様に潜水調査 船を含むさまざま詳細な研究が諸処で行われ，両タイプ の熱水鈗休の存在が確認されただけでなく, 1979 年に なつて潜水調査船アルビン号が EPR の北緯 $21^{\circ}$ 地域 (カリフォルニア湾口沖合) で史上最初の大発見を行つ た. それは, 水深約 $2600 \mathrm{~m}$ で複雑な凹凸地形の払大軸 (プレート境界) の海底に括いて玄武岩の上に高さ数 $\mathrm{m}$ 程度の大小の多数の煙突（噴出口; ベントあるいはチム ニ一と呼ばれている) がならび, そこから黒い煙が勢い よく噴き上がつているといら光景であつた．その黒い煙 は約 $350^{\circ} \mathrm{C}$ に達する高温を示し，海底下に起源をもつ 䯚濁した硫化鉄からなる熱水溶液であつた．煙突は亜 鉛・銅・鉄等の硫化鉱物であり，同様な硫化釷物からな る大小の塊りがその周辺に存在していたのである. 東太 平洋の中央海嶺拡大軸の研究はこれを契機として諸所に おいて急速に進展し, 同様なチム二一や高温・還元型の 塊状硫化物鉱床が低温・酸化型のものと共に, EPR 北 緯 $13^{\circ}$ 地域, ファンデフーカ海嶺, ガラパゴス払大軸 その他の地域に打いてあいついで発見された。なかで も，1981 年にガラパゴス拡大軸西経 $86^{\circ}$ 地域において 巨大な（高さ $35 \mathrm{~m}$ に達する）活動を停止したチムニー が, $20 \sim 200 \mathrm{~m}$ の幅, $1 \mathrm{~km}$ 程度の範囲に互いにゆ着し あつたような形で林立していることが発見されたこと は，拡大軸に拈ける塊状硫化物鉱床の大きな資源的価值 の可能性追求の端緒となつた。これまでに, 図 2 にみら れるように東太平洋の拡大軸ぞいに北緯 $50^{\circ}$ 付近 (バン クーバー沖；エクスプローラ海嶺）から南緯 $20^{\circ}$ 付近に わたつて諸所で塊状硫化物鉱床が発見されている. それ らのなかで, とくにェクスプローラ海嶺, ゴルダ海嶺, ファンデフーカ海嶺はカナダ，米国の 200 海里水域に 属し, 将来独自に開発が可能であることから両国によつ て著しく注目され，探査がすすんできた. エクスプロー ラ海嶺では当初低温・酸化型のものしか知られていなか つたがカナダの科学者による詳細な調査の 結果, 1984 年夏にはじめて少なくとも 150 万 $\mathrm{t}$ 以上といわれる銅・ 亜鉛硫化物鉱床が発見されたのであつた。

これまでに知られている限り, 払大軸部に扰ける塊状 硫化物鉱床の産状・諸性質にはかなりの共通性が認めら れる. 同鉱床はせまい中軸谷（水深 $2000 \sim 2600 \mathrm{~m}$ 程 


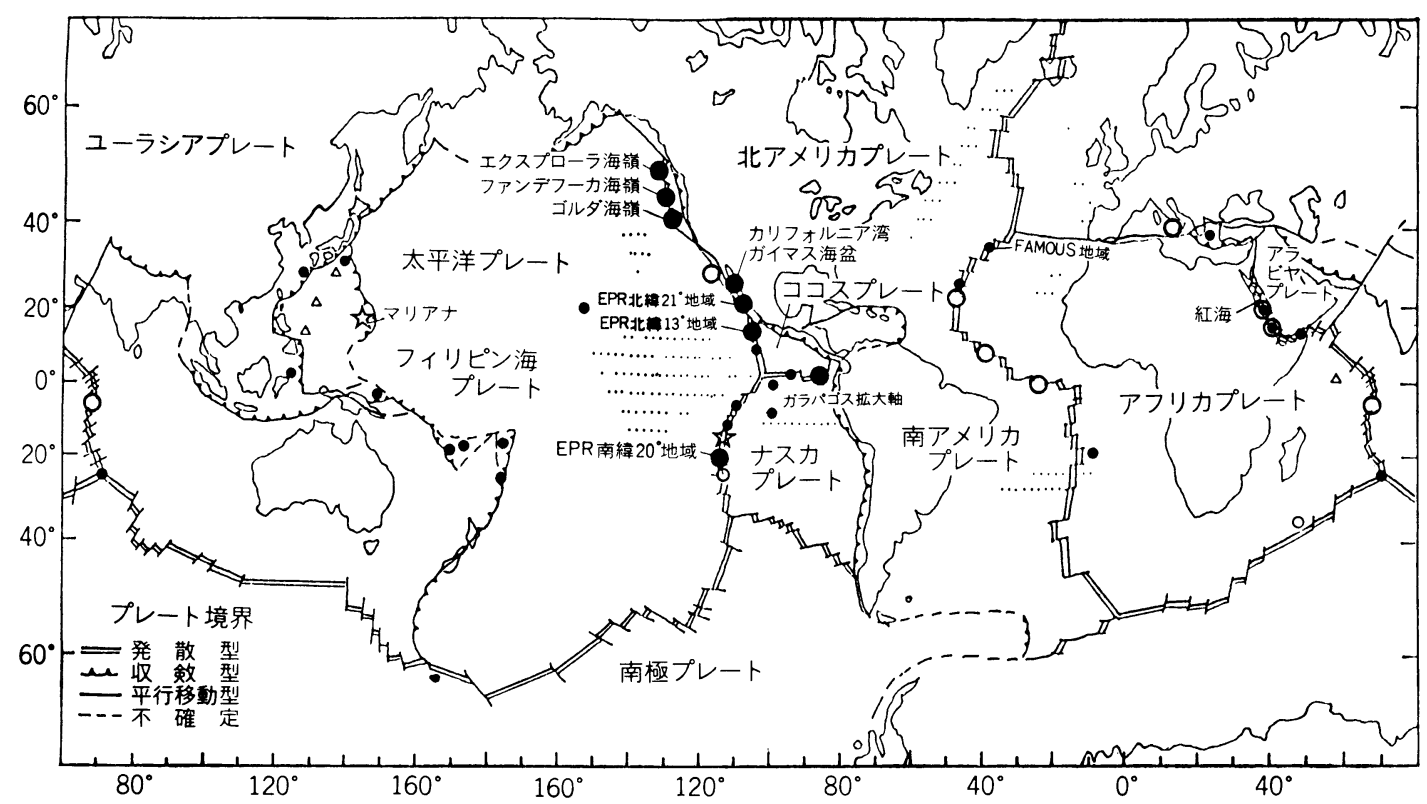

汹2 プレ一ト境界々熱水鉱床及び熱水起源含重金属の堆積物の分布 大きな黒丸一塊状硫化物. 小さな黒丸一鉄マンガン酸化物. 大きな闪一硫酸㙁。二重丸一紅海の重金属泥 星印一塊状硫化物の存在が強く推定さ机ているとてろ。

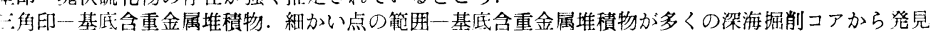

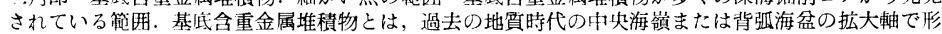
成された熱水求源の重金属に之离堆皘物が形成後のプレートの移動，その上位での堆皘物の堆皘に伴 つて, 遠隔地に移動し, 現在, 厚い堆皘/圈の基底（大洋底玄武岩の直上）に埋没しているものの総称 である、深海掘削の手段によつてのみ発見か河能である。

度）のなか，あるいはその周辺に玄武岩上にあり，熱水 を噴出する活動的チムニー, あるいはすでに活動を停止 したチムニー, あるいはマウンド等として存在する.こ れらはウルツ鉱・閃严鉛鉱・黄銅鈗・黄鉄鉱・磁硫鉄鉱 を主とし, 化学組成上亜鉛硫化物系, 銅硫化物系に大別さ れる. 最大 $350^{\circ} \mathrm{C}$ あるいはそれ以上の温度に達する噴 出した熱水から上記の諸鉱物が沈澱, チムニーを成長さ せるが，その成長速度は 1 日当たり $8 \mathrm{~cm}$ 前後という測 定例が一部で知られている. 高温・還元型のものと同時 に低温・酸化型の鉄・マンガン酸化物も諸所に沈澱して いる. 硫化物の金属含有量はばらつきが大きいが, 最大 值をとると亜鉛約 $60 \%$, 銅約 $6.5 \%$, 銀 $300 \mathrm{ppm}$ に達 している．噴出する熱水はマントル起源と考えられる一 リウム, メタン, 水素は多く含まれるほか, マンガンそ の他若干の金属に富んでいる.とくにへリウム, メタ ン, マンガンは直上のウォータコラム中に濃集する傾向 を示し, 探查のためのよい指標となつている. 塊状硫化 物鉱床地带では, 地下の活発なマグマ溜りの活動, 活発 な熱水循環, 熱水による岩石の変質等を反映して, ブー ゲー重力異常の低下, 火山性微小地震活動, 地震波速度 の減衰, 岩石の残留磁気強度の低下, 高地㪍熱流量值と 低地殼熱流量值の周期的な地理的変動等の地球物理学的
な特異性が認められ，これらも探査のためのよい指標と なつている.

さて, 熱水起源の鉱床は図 2 にみられるよらに世界の 中央海嶺の中軸部ぞいに分布しているが，これまでのと ころ塊状硫化物が知られているのは東太平洋域のみであ つて, それ以外からは知られていない。これは発散型プ レート境界 (中央海嶺の拡大軸) に打けるプレートの拡 大速度の相違に関連した地下の構造, マグマ溜りや熱水 循環の状態の相違によるものと考えられる. 中央海嶺の 拡大軸は場所によりさまざまな拡大速度を示している。 熱水鉱床が知られているところについてみると, 東太平 洋の拡大軸では 4 $19 \mathrm{~cm} /$ 年であり, いつぽら大西洋中 央海領の拡大軸では $2 \sim 4 \mathrm{~cm} /$ 年である. 拡大軸は一般 におそい拡大速度のもの (4 cm/年以下), 中程度の拡大 速度のもの (4 $6 \mathrm{~cm} /$ 年), はやい拡大速度のもの $(6$ $\mathrm{cm} /$ 年以上) にわけられている. これまでの諸観測デー タによると, 拡大速度が中程度ないしはやい拡大軸では マグマ溜りは海底下 $0.5 \sim 1 \mathrm{~km}$ まで上昇し， $5 \mathrm{~km}$ 程度 の深さで約 $20 \mathrm{~km}$ の広がりを持つたくさび状であり, さらにマグマ溜りの上には付ずい的にキューポラといわ れる小さなマグマ溜りが存在する. 平均地温勾配は約 2 ${ }^{\circ} \mathrm{C} / \mathrm{m}$ と考えられる. このよらな場合には地下の残所に 


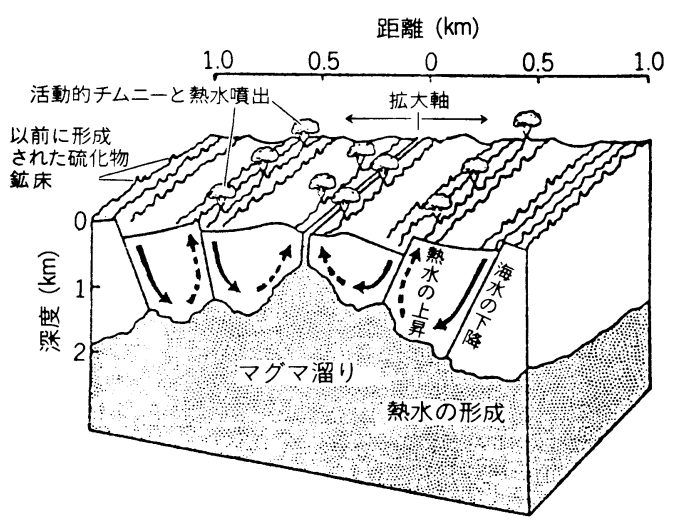

図 3 中央海嶺の搪大軸における熱水循環と塊状硫 化物の形成（Rona 1982, MTS J., 16[3],

Fig. 2 にもとー゙く)

断首・割れ目等にそつて地下深く浸透した海水は加熱される と同時に, マグマ溜り, 周囲の岩石から諸金属成分がそのな かに入り込み熱水が形成される。、ントル起源の物質も一部 付加される. 形成された密度の小さい高温の熱水は割れ目を 伝つて海底まで上昇し，その途中あるいは海底上㵞水性の 塊状硫化物鉱床を沈汯させる。

高温の熱水系が存在でき, 熱水が海底に噴出するまで高 温・還元性に保たれ, 銅一亜鉛一鉄の塊状硫化物が海底で 熱水から沈殿, 形成される (図 3 ). いつぽら, 大西洋 中央海嶺のよらに拡大速度がおそい拡大軸では, マグマ 溜りははるかに深く位置し, 約 $3.5 \mathrm{~km}$ の深さに頂部を もつ比較的せまいマグマ溜りとなつている. 平均地温勾 配は約 $0.3^{\circ} \mathrm{C} / \mathrm{m}$ と非常に小さい. 地下深所で形成され た熱水は上昇する過程で下降してくる新鮮な海水との混 合によつて温度が低下し, かつ酸化性となる. その結 果, 海底には鉄マンガン酸化物が沈澱する. 硫化物は海 底下の玄武岩中に分散状, 鉱染状, あるいは塊状に沈澱 していると推定されている.

発散型プレート境界における熱水鉱床形成のプロセス について, 巨視的には上記のような説明が可能であると してもまだ問題は残されている. 東太平洋の中央海嶺中 軸部では諸所で硫化物と酸化物がわずかに隔つて存在し ている. 海底下のマグマ溜りや熱水系の発達状況の地理 的な変動を示すものか, あるいはそれらが時代的に異な つているのか, 海底で硫化物を形成するような熱水作用 は拡大軸ぞいにどの程度の間隔でおこつているのか, 硫 化物中の高品位の亜鉛の濃度はどのよらなプロセスによ るのか等, 発散型プレート境界そのものの性質を明らか にする上に重要な key となり， また資源探査の上にも 同時に重要である基礎的な面が未解決なまま残されてい るのである。

いつぽら, 収斂型プレート境界は発散型プレート境界

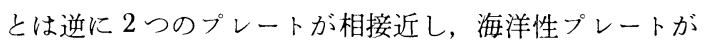
大陸性プレートの下に沈み込んでいくところであり, 沈 み込んだプレートは地下深部でやがてアセノスフェアに
一体化されていく、沈み込みは大陸縁辺部と大洋底を境 する海溝に沿つて行われる. 沈み込みに伴つてさまざま な地球科学的現象がおこるが, 典型的には二つのタイプ にわけられる.すなわち, チリ型とマリアナ型である. 前者では現在南米の西部にみられるよらに海溝の陸側が 大陸となつている.いつぽら後者では現在マリアナ地域 にみられるよらに海溝の陸側に島弧を隔てて,すなわち 島弧一海溝系の大陸側に背弧海盆が形成されつつある. このちがいは沈み込むプレートの形態や性質に関連して いると考えられる。そしてそれは時代的に変化してきた と考えられるものである.

背弧海盆は，マリアナ型の沈み込みの大陸側に伸長性 テクトニクス場が生じ, 新しい海底地款の誕生と海洋底 桩大が，すなわち背弧桩大がおこることによつて形成さ れると考えられる，さまざまなデータは，大洋の中央海 嶺と同じょらに, 背弧海盆にも高熱流量值によつて特徵 づけられ起伏のはげしい払大軸があり, それを中心とし て地磁気縞模样が認められることが多いことを示してい る. 現在みられる背弧海盆の多くは過去の地質時代に形 成されたものであり，拡大軸は堆積物によつて埋積され ていることが多い。しかし，一部のものは現在拡大中で あり，拡大軸あるいは火山体の近くに活発な熱水活動が 期待される. マリアナトラフはその典型例である。

マリアナトラフは約 500 万年前以来平均 $4.3 \mathrm{~cm} /$ 年 の速度で背弧拡大を行つてきた。拡大軸付近での高熱流 量・低熱流量值の周期的変動, はげしい地形的起伏, ウ ォータコラム中のメタン, ヘリウム異常, 堆積物中の熱 水性鉱物の存在, 熱水性鉄マンガン酸化物の存在等, 中 央海嶺と同様な地下における活発な熱水循環を示す証拠 が多く得られている.このよらなことからここにおいて も熱水噴出口や高温・還元型の塊状硫化物の存在が十分 に推定され，国際的に大きな注目をあびている. 現在日 米の科学者の協力によるアルビン号潜航調查が計画され ており，その成果はまだ十分に解明されていない背弧海 盆の地下構造や拡大機構の問題に，またまだ塊状硫化物 が発見されていない他の背弧海盆における今後の研究に 画期的な貢献となることが予想される.

マリアナトラフの北側には, 南硫黄島から八丈島, さ らに北方へと連なる火山からなる七島一硫黄島海領があ る. またそのすぐ西側にはマリアナトラフと類似の性格 を持つ,「小笠原弧の背弧凹地」とよばれているリフト 地形が断続的に南北にわたつて発達している. まだ明確 な証拠は得られていないが，諸データから，その一部は 80 万〜 90 万年前から挫大を開始した，いわば背弧海盆 形成の初期段階にあると考えられている. 周辺及び凹地 内には火山活動が認められ, 日本列島に特徵的に分布す る銅・鉛・亜鉛を主とする黒鉱鉱床はかつてのこのよう な凹地に形成されたのではないかといら考え方もあり， 現在の塊状硫化物の形成の可能性がマリアナトラフと同 
様に注目されているところである。【業技術院地質調査 所では昭和 59 年からこの海域に対して詳細な研究を実 施している。来だ塊状硫化物は発見されていないが，八 大島付近や西七島海頜の海山に低温・酸化型の熱水性鉄 マンガン酸化物が分布し，地トで熱水循環が行われてい ることが明らかとなつた。この海域の一部については数 年後ジョイデスレッ゙リューション号を使用しての国際深 海掘削計画 (ODP) に上る深海掘削が検討されている. これらの研究の進展により, マリアナトラフと同椂に, 塊状硫化物の発見, 初期段階の背弧拡大の詳細の解明が 著しくす寸をことが期待される.

収斂型プレート境界におい、て伍か江熱水鉱休が形成さ れつつある可能性のある海域は, 日本周辺では沖縄トラ フ, 南西太平洋の背弧海盆と島弧（ラウ海盆，ウッドラ ーク海盆, ビスマルク海等), インド洋北東部のアンダ マン海などである。これらの大部分から熱水性の鉄マン ガン酸化物や重金属に富む堆皘物が知られており, 塊 状硫化物の今後の発見が国際的に注目されている.収斂 型プレート境界の現在拡大中の背弧海盆においては諸処 で熱水循環が括こつている。 そして発散型プレート境界 と類似の地質地球物理学的な構造となつており, 海盆で の熱水噴出とそれに伴ら高温・還元型の塊状硫化物の形 成が予想されるわけであるが，発見されるとすれば，大 陸性地殼中の熱水循環に伴つて海洋性地殼のみからなる 大洋中央海嶺の場合とはやや異なつて, 黒鉱鉱床に類似 して, 銅・鉛・亜鉛・金・銀・バリウム・などに富む注 か, とくにゲルマニウム, ガリウム、インジウム, タリ ウム等のレアメタルを少なからず含むであるらといら意 見がある。

東太平洋の中央海領の塊状硫化物についてはとくに米 国・カナダの沖合いのものは両国の 200 海里水域内に 存在するといらことから両国によつて著しく注目されて いることを先に述べた，一方では，主要金属，鉛・亜鉛 等の将来の需給関係（代替品の開発によつて影響を受け る), 探查・開発のコストなどの予測結果から塊状硫化 物の商業的価值を疑問視する見解も出されているが，い ずれにせよ, 資源的価值の評価のもととなる塊状硫化物 の分布, 鉱床としての規模・性状など, 著しくデータが 少ないのが現状であり, 背弧海盆も合わせて今後の詳細 な全体的アセスメントが是非必要である.

我が国はいらまでもなく金属鉱物資源に著しく乏し く、レアメタル, ベースメタルともに大部分を海外に依 存している. 将米, それらのうち, マンガン・ニッケ ル・銅については深海底のマンガン団塊にもとめること ができようが，他の金属についてはそらいら事情にはな い.そこでクローズドアッブしてくるのが，塊状硫化物 である. 東太平洋の中央海嶺の塊状硫化物は亜鉛・銅を 豊富に含むほか金・銀・鉛, その他のレアメタルを含ん でいる. 背弧海盆に期待される塊状硫化物は, さらに多
くのレアメタルが含まれている可能性がある。となる と, とくに注目に值するのは我が国の 200 海里水域内 に位置する「小笠原弧の背弧凹地」及びその周辺の火山 地帯である。また, マリアナトラフや南西太平洋の背弧 海盆についても将来の国際共同開発の可能性の点から目 を向ける必要がある。「小笠原弧の背弧凹地」及びその 周辺域については, 先述の上うに工業技術院地質調查所 がシステマティックな, 組織的な研究を 59 年から開始 し，すでに将来の探査に対して基礎となるよい成果をあ げている. 東太平洋の公海水域内にある中央海嶺の塊状 硫化物については，すでに報じられているように昭和 60 年から金属鉱業事業団が通商産業省の委託による海底熱 水鉱床探查を開始した．今後継続的に，探査がす寸めら れることになつている.なお, プレートテクトニクスと 背弧海盆の熱水循環・鉱布形成といら純学術的観点から は, 東大地震研究所, 東大海洋研究所, 東海大学の研究 者グループが中心となつて, 沖縄トラフ, マリアナトラ フに関する研究がす寸められつつある.

海底熱水鉱床の探査・研究手法は70 年代からすでに 仏・米両国に打いて検討され，この10 年間著しい改 善, 新機器・手法の開発がなされてきた。すでにふれた 地球物理的 - 地球化学的示標の検出のほか, 直接的な手 段としてナロービーム音響測深機, サイドスキャンソー ナ等の音響的方法, 試料採取, さらに潜水調查船に上る 潜航目視調查・試料採取等, 極めて効果的である. とく に音響的方法についての研究開発は米国において著しい ものがある，次に，まず問題になるのはどのように塊状 硫化物を採掘するかといら技術である. 現在いくつかの 採掘システムの案が検討されているが, 基本的には, 鉱 体の粉砕と集鉱, スラリ一化, 揚鈗のシステムから構成 され, また, 動力・信号複合ケーブル, 船上からの遠隔 操作技術等は重要な要素となる。いずれにせよ深海の高 压・暗黒・低温の環境下で, かつ地形的に複雑なところ で比較的小さな, 不規則な形の鈗体の群を対象とするの で, マンガン団塊の採掘にくらべてはるかに困難であ り, まず, 高度な要素技術の開発, それらのシステム化 が必要となる. 現在す寸みつつあるいわゆる局限技術の 研究開発の成果はとの重要な基礎の一つとなろら。 また 一方では，この技術開発は高度な応用・波及効果を持つ ているといえよう。

以上に，塊状硫化物を中心とする海底熱水鈗床のプレ 一トテクトニクスとの成因的関係, 知られている性状 等, 探查・開発の現状などを概観した，海底熱水釷休の 発見はプレートテクトニクス研究発展の大きな成果の一 つであり，一方ではそれはこれまで十分に知られていな かつたプレート境界の地下深部に関する科学的認識を深 め, プレートテクトニクスのいつそらの発展に大きな寄 与をしているといえる。とはいうものの, 海底熱水鉱床 についてはまだわかつていないことが多々あり, 今後の 
研究・探査により，上記の関係がますます発展すること が十分に子想できるのである.さらに，海底熱水鈗床の 探查, 採掘の技術開発は大規模な経費を要するものであ るが, 我が国の将来の経済安全保障といら観点から,さ らに期待される高度な応用・波及効果といら観点からも 積極的に継続的に発展させる必要がある.なお，とくに 探查についてはこれまでの諸外国の経験が示すように塊 状硫化物の発見自体が，かりに存在するとしても極めて 困難なるのであり, ある意味では試掘に上る石油の探査・ 発見とにたよらな状況下にある.気長な，そして十分な 投資による探查によつてはじめて成功する場合が多いと いらことをあらかじめ認識しておく必要がある。

\section{文献}

1）資源調䍒会編：海底熱水鉣休に関寸る基礎調查， 資料 No. 120 (1984)，p. 365 [科学技術方資源調 查所]

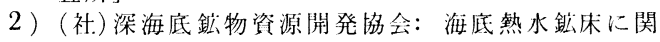
寸る調查研究報告書 (1984), p. 340

3 ) (社) 深海底鈗物资源開発協会: 海底熱水鈗休に関 する調榃研究報告書 (1985), p. 239

4 ）工学技術院地質調查所：海底熱水鉣林の調相技術 飞関する調查報告, 我が国周辺 200 海里水域の調 査手法に関するフィージビリティースタディ (1983), p. 58

5 ）工学技術院地質調査所：海底熟水活動心伴ら重金 属資源の評価手法に関する研究 (1985), p. 99

6) 上記の汪か, 月刊海洋科学, 15 (1983) $9 ; 15$ (1983) 10 [海洋出版(株) ] は熱水鈗床特集号とし て, 計 27 編の熱水鉱床に関する論文を揭載して いる. 


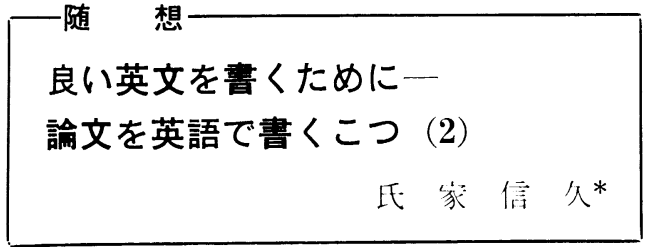

はじめに

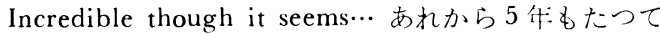
しまつた。

あれといらのは，筆者がこの前，“良い英文を書くため に一論文を英語で書くこつ一”をこの随想闌に投稿した 時のことで，それは1981 年(第67 年)第1号であつた1). その時, Trans. ISIJ はつつの転機を迎えていた。我 が国の製鉄・製鋼・加 [.の科学・技術が世界的な優越性 を確立するに従つて，『鉄と鋼』を始めとする学術誌・ 技術誌の論文が，著者に対する挨拶も万くに一往々に して全くなく，しかも営利的に，翻訳されるケー が目に余るよらになつたのである.

これに対して，協会は：つの手を打つた。そのいは， 日本鉄鋼協会の全出版物に著作権を設走することであ り，その三は，『鉄之鋼』に採択された論文の多くが， Trans. ISIJ に投稿されるよらに働きかけることであつ た．筆者の“論文を英語で書くこつ”は, 編集委員会欧 文誌分科会の同意を得て，他の数編の御寄稿と共にこ の第：の目的で，鉄と鋼』に揭載していただいたもので ある、そしてこの小文で, 私は, 「我々の使う英語は, 英 米人が国語とする英語では無く, 科学・技術の世界に於 ける国際語としての英語である との立場から，Trans. ISIJ 投稿原稿によく見られる，文法的に間違つている 訳ではないので, 英米人にみせても直してくれないが, 重大な䛊解の種となり兼㸚ない語法や表現をとり上げる ことにした，そして，第・回のつもりで，「1. 主語」 では editor's we の用法,「2, 関係代名詞」では“that” と, “which”の使い分け，そして 3 . 分詞構文」では 前置詞へと進化してしまつた現在分詞と dangling participle との違い, の問題を解説した.

あれから5年の歳月が，それこそアッといら間にたつ てしまつた。 日本の鉄鋼の科学・技術の優位は, 摇るぎ なく確定されたし，また，Trans. ISIJに，優れた original 論文が数多く投稿されるよらにもなつた。更に, 著作権設定のお蒢で, 無許可営業の翻訳も, 少くともお おつぴらには, 行われなくなつた. しかし, 欧文誌分科 会としては,『鉄と鋼』の読者の皆さんに, Trans. ISIJ への御投稿を，もつともつと盛んにしていただきたい, それはトップの㭫を占めた者の obligation である，と 考えている。

今回の投稿は、この願いをこめて行つた。論旨，論調

* 石川島播磨重工業(株)技術研究所 Dr. Eng.
とも，前稿と全く同じなので，その続編として読んでい ただきたい，幸いにして連載が許可されれば，4，動詞，

5. 形容詞, 6。前置詞・熟語 - 熟語動詞, 7. 助動詞,

8.ラテン語と，英作文上の問題点と対策を考えていき たい。

\section{4. 動 詞}

(1) Consider the dog dead.

(2) Consider this proposition.

(3) Consider the price.

(4) Consider her feelings.

科学技術論文は公式文書である，従つて，使われる字 句も，それにふさわしい重みがあるものを選びたい，そ れは全く正しい，そこで，非常に多くの人達が， think と言いたい時 consider を使いたがる一それも it is considered that $\cdots$ の形で.

しかし，上の例文を見ていただきたい。

まず，(1）では，君は新聞を配達している所だ。恐 ろしい顔をした犬が，牙をむき出してウーッとらなつて いる。そこで，君は自分に言いきかす。『あの犬は，死 んでいると考える・』つまり，この場合，“考える”は “みなす”で, consider=regard asなのだ.

次に，(2) では，君はブロフェッサーだ. 君は黒板 に何やら難かしい数式を書さ，おもむろに就れな学生を にらみつけて言5。『この命題を考えて見たまえ・』すな おち，君の“考えよ”は“吟味せよ”で,この場合 consider=examine にほかならない。

次の（3）では，君はドラ息子にスボーツカーをねだ られているオヤジだ。車の性能論では全然かなわないの で，君はせめてオヤジの威敨をみせて言つてやるのだ。 『值段のことを考えろ・』つまりここでは, consider が take into account の意味で使われている.

最後の (4)では, 君は新入女子社員の教育を猛烈にや つている係長を，心配しながら見ている課長さんだ。ち よつと行き過ぎだと思つた君は，係長を物院に呼んで注 意してやるのだ。『あの娘の気持も考えてやれよ・そし て, この場合の consider は, “尊重する”, すなわち pay respect to なのだ.

上の 4 例は，現代英語に於ける日常会話での頻度の 順ではない一例えば, Oxford Universal Dictionary (Oxford English Dictionary の短縮版) には 9 種の意 味が出ていて，その歴史的な出現順は $2,3,4,1$ とさ れており，また，Longman Dictionary of Contemporary English では，2，1，3（4 を含む）となつている. しかし，科学技術論文に現れる consider は，一別に統 計をとつた訳ではないが, 一概して上のようで, consider がお望みの “熟慮”の意味そのもので使われるのは, This is my considered opinion.（これが私の熟慮の結 果の意見である.) ぐらいしか見当たらないのである.

つまり，consider は，“良く考える”には違いないの 
だが, think の偉い言葉ではなく, it is considered は, “...と思ら”ないしは“…思われる”の荘重版ではな いのである．英語でも米語でも， it is considered that ․と言われて，まずヒンとくるのは，これは it is generally regarded that‥の意味, すなわち, that 以下 は, 当業界の誰でもそう思つている常識と理解するこ とで，次に，それでは文意が通らなければ，著者が非英 語国民であることを考慮 (consider) して，it is consid-

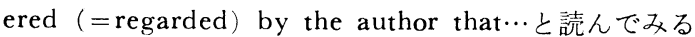
かと言らことになるのである。この故に，不用意に

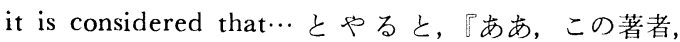
苦しまぎれに勝手な仮定を置いたな』などと，あら奴疑 いをかけられてしまわないとも限らない。

もちろん，それを逆に使つて，あまりくどくどしくな りそらなとき，言葉での記述はデータの提示とポイント を衝く説明のみとし，後は読者の判断に任せる，といつ た気持で，“The effects of this factor are considered demonstrated.”などとするのは，完全に正当的で，ま たうをい書き方である。

一方，和文原稿の方も，上述の事情に対応できるよう にしておくべきであろら．この表現，科学技術論文での “…思われる”は, 我々日本人の間では, “著者おも5 に‥”の意として結構通るが, 実は, 誰が, どらいら風 に“思つた”のかがあいまいなので，それは無責任な 表現とされてしまう。そして，これが英文に翻訳される と、よほど物の分かつた人でもなければ,ごく自然に “it is considered that...”となり，上述の悲劇の種を蒔 くことになる．この場合，英米人にみてもらつても，文 法的に間違つている訳ではないので，見過されてしまう 一その人もやはり，著者が仮定しているなと consider するだけのこと一ので, 御注意いただきたい.

従つて, ここはもつと強く，もつとはつきりと表現し て, 結論する, 判断する, 推測する, 主張する, などを 使うべきであり，英文では， considerしている主体を 明瞭にして, the author concludes $\cdots$, the author sub-

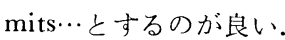

これに対して, think はもつと直感的, 従つて主観的 なものであるから，著者の過去に於ける経験の表明とし て, “it was observed (=I observed) that...” と同様 に, 例えば, “It was thought then that a lower temperature would accomplish the purpose.”之言うふら にすれば良い。

\section{まと女}

（1） considerは，上の 4 例に該当する意味でのみ使 5.-.-. think の代わりには使わない.

（2）日本文での“・・・思われる”は，英文化さ れると“it is considered that …となり，それは 『・・とみなす」の意味となつてしまらから，特に御 注意願いたい。
（3）一般に，『・・思う』に対する表現は, もつ と強く, また明快に, the author concludes that $\cdots$, the author submits that $\cdots$, the author postulates that $\cdots な$ どと，責任の所在が明確になるように書く.

(4) think は think で立派な言葉であるが，それは 著者のみの経験であつて，客観的に科量できるものでは ないから，“it was thought””のよらに，過去におけ る事実の報告として表現すれば良い。

\section{5. 形容詞}

犬が人を喵んだつて……フ

人が犬を喵んだって一- Remarkable !

我々が書く論文，少なくとも Trans. ISIJに投稿され る論文には, “大きい”，つまり great と言う時, remarkableとしたものが非常に多い-The increase was remarkable. といらように. 英語として, remarkable は れつきとした良い言葉である。しかし，それは時と場合 によりけりで，使い方にはちよつとしたコッがいる。

まず, remarkable は remark+able であり, 更に remark は“コメントする気持でいに出して言う”の意 味であるから，結局 remarkable とは，“特筆する”な いしは“特記する”に対して，いらならば“特言に值す る”といらことだと認識していただきたい、つまり,こ れはもともと主観性の強い, またかなり感情的な言葉で あつて，例えば，上例では，人が犬を啮んだつて，フ ン，何だ，そんなこと，と思ら人も多いだろうし，ま た，人を嚙んだ犬が，もし盲導犬だつたとしたら，そし て，もし君がブンヤさんだつたら，盲導犬は決してそん なことをしないように教育されているから，“Remarkable！何かあるに違いない.”と飛び出して行くであ 万ら.

従つて，科学技術論文で remarkable を使ら時は，万 人が“特筆に值する”と合意してくれるであろら場合に 限るべきである，具体的には，例えば，増加が‥ト桁以 上であれば，自他共に認める remarkable increase と 言えようが，2，3 倍ではまあまあといつたところであ ろらし（2 倍すればひと桁あがる場合が多いことに御注. 意)，それが $2,30 \%$ 程度なら一も七ろん物にもよろら が一, remarkable と思らのは君の独りよがりと言われ ても，仕方あるまい。

それはおかしい, 俺は有名な先生が remarkableを論 文の中で盛んに使つているのを読んだことがある，と抗 議される向きが多いと思ら。しかし，良く思い出してい ただきたい: それは, 展望, 総説, 解説, 教科書の類で はなかつただろらか？前回1)の 1 ．立語で述べたよう に, 報告書や人文科学系の論文も含めて, それらは甘観 性, 直感性が尊重されるべきものであつて, 客観性が生 命であるはずの研究論文とは性格を買にすることを考え ていただきたい，

いずれにせよ，上に述べたように，remarkable は， 
心得て使いさえすれば，切れのいい良い言葉であつて， 定性的な表現では，例えば理論值と実験值の合致度合な らば, 良から悪の順に, superb, remarkable, excellent, good, fair, bad, non at all である.ただし, superbは commercialese (宣伝語) だからよほどのことでもな けれ使らべきではない（科学技術論文で superb が正 当に使える人には，この記事を読む資格が無い). 一方， 数量的な表現には，小から大の順に， noticeable (perceptible), appreciable, substantial, considerable, enormous となり, substantial と considerable でいわ ゆる“相当な”で表現される範用をカバーする，もちろ ん，著者の一方的な宣言にならないよらに，データの提 示は最低の前提条件であり，また，幾ら数量的と言つて も, 全く定量性は無いから，著者の気持を伝えるだけと 考えていただきたい。

更に言えば，研究論文では，形容詞はなるべく使わな
い, 使ら場合には控え日の言葉を選ぶのが良い。例え ば，上例で excellent と言いたくても，Agreement is rather good.ぐらいで我慢しておくのがュッである.こ らいつた understatement が君の論文に a great deal of credibility を与えるだけでなく, a good deal of force をも与えてくれるのである.

まとめ

(1) remarkable は“びつくりした, ‘特言”に值す る”と, 読者が誰でも認めてくれるであろら時にのみ使 ら.

（2）一般に，研究論文では，形容詞はできるだけ使 わない力がいい, 主観性を排し, 客観性を保つためであ る.

\section{交献}

1) 氏家信久: 鉄と鋼, 67 (1981), p. 200 